\title{
CONSUMPTIVE USE OF WATER BY SELECTED CASH CROPS IN MALAYSIA
}

\author{
Siti Norliyana Haruna ${ }^{1}$, Marlia M. Hanafiah ${ }^{1^{*}}$
}

${ }^{1}$ School of Environmental and Natural Resource Sciences, Faculty of Science and Technology, Universiti Kebangsaan

Malaysia, 43600 Bangi, Selangor, Malaysia

\section{*Corresponding author email: mhmarlia@ukm.edu.my}

This is an open access article distributed under the Creative Commons Attribution License, which permits unrestricted use, distribution, and reproduction in any medium, provided the original work is properly cited

\begin{tabular}{|c|c|}
\hline ARTICLE DETAILS & ABSTRACT \\
\hline Article history: & rapid development in economic sectors has induced the water depletion in most of the developing country, \\
\hline Received 12 September 2017 & particularly for Malaysia. This study estimates the consumptive water use of cultivating 5 cash crops, i.e. cassava, \\
\hline Accepted 19 October 2017 & maize, rice, sugarcane and sweet potato in Peninsular Malaysia. The consumptive water uses for cultivating these 5 \\
\hline Available online 30 October 2017 & $\begin{array}{l}\text { crops was determined based on the CROPWAT } 8.0 \text { and Penman Monteith model. CROPWAT } 8.0 \text { model was used to } \\
\text { compute the evapotranspiration and crop water requirement (effective rainfall and irrigation requirement) of the }\end{array}$ \\
\hline Keywords: & $\begin{array}{l}\text { cash crops grown in Peninsular Malaysia from 2005-2013 ( } 9 \text { years). It was found that the green water uses for } \\
\text { cultivating cassava, maize, paddy, sugarcane and sweet potato for Peninsular Malaysia is higher than the blue water }\end{array}$ \\
\hline Water Footprint; Water stress index; & use. In conclusion, water use for cultivating agricultural crops will accelerate the competition on the consumption of \\
\hline $\begin{array}{l}\text { Water deprivation; Agriculture sector; } \\
\text { Malaysia }\end{array}$ & clean water with the other sectors. However, the availability of water resource in Peninsular Malaysia is sufficient to \\
\hline
\end{tabular}

\section{INTRODUCTION}

Water consumption has growing faster than the population growth [1]. This continuous trend unfortunately has led to an issue of water scarcity and it is estimated that about half of the world population will face problem accessing safe water supply to support their daily routine by year 2025 [1]. Domestic, agriculture and industrial sectors are the largest consumers of water will further accelerate the problem of water shortage [2]. According to the World Water Assessment Programme, agriculture is one of the highest users for water consumption [3]. It is predicted that the global water consumption for agriculture to reach to $8,515 \mathrm{~km} 3$ per year or to increase $19 \%$ by year 2025 .

As in Malaysia, agriculture sector plays an important role in national economic development. It helps secure the national food security and also arouses public incomes especially for people living in rural areas. Given its natural advantages, agriculture and livestock sub-sectors play an important role in ensuring Malaysian food security. Cassava, maize, rice, sugarcane and sweet potato are considered as cash crops in Malaysia. For the past 50 years, the government has allocated billions of Ringgits to maximise Malaysian agriculture production [4]. Due to this scenario, farmers across the world including Malaysia have taken a step further in strengthening its food security.

The water footprint analysis can be used to determine the actual amount of water used for the entire process of producing agricultural product. The amount of blue water use from agriculture production can help us to determine the total amount of surface water consumed for producing crops. The results from this study are expected to convey the overall amount of consumptive water used by the selected cash crops in Malaysia. This study will be a starting point to assess the amount of water consumed from crops farming using a comprehensive and holistic water footprint approach. This study is also expected to provide benefits to agencies, policy makers and industries pertaining to the cash crops sector. This baseline information can be used to identify which area that needs to be conserved and what type of recommendation that should be drawn. Furthermore, it offers a number of benefits such as to identify the 'hotspots' in the value chain of activities and enhance initiatives towards sustainable agricultural practice and wise water management in Malaysia.

\section{METHODOLOGY}

In this research, data were compiled from a various secondary data sources such as books, publications, reports, government agencies including the Department of Irrigation and Drainage, Malaysian Meteorological Department, Department of Agriculture for Peninsular Malaysia, Department of Statistic, MARDI and National Water Services Commission that related to the field of studies; Malaysian rice cultivation and Malaysian hydrological information. Meanwhile, foreground data were obtained through a series of site visits by communicating with data providers, and developing questionnaires.
For water footprint analysis, climatic data consists of minimum and maximum temperature, humidity, sunshine, rainfall rate and wind speed for 9 years (2005 to 2013) was used to estimate the crop water use. Crop water requirements and irrigation requirements were calculated using CROPWAT 8.0 Model, a decision support tool developed by the Land and Water Development Division of FAO. Besides climatic data, other parameters such as crop data and soil condition were included in the CROPWAT 8.0 model to estimate crop performance under both rainfed and irrigated conditions.

In this study, the evapotranspiration rate was determined using the Penman-Monteith method. A statistical analysis was also used to estimate the rainfall deficit for irrigation water requirements based on long-term rainfall records. This analysis was determined as part of the rainfall which effectively contributes to cover crop water requirements (CWR). Information on inventory database was compiled and all data were used to model a water footprint of the selected cash crops cultivation in Malaysia. Finally, a set of recommendations and suggestions was given.

\subsection{Assessment of Water Footprint}

Proper management of water resources is important, specifically when resources are limited [5]. Availability of water for population and its economic activities is important when managing the optimum use of water resources. Estimating consumptive water use by crops cultivation can be conducted using the method of water footprint. Water footprint is a tool that has been introduced by a researcher to assess and quantify the water required for production of a product [6]. Water footprint can also serve as a medium to assess the potential environmental impacts related to water $[7,8,9]$.

Water footprint consists of three components which are specified geographically and temporally; green, blue and grey water. Green water footprint refers to the total rainwater evapotranspiration and water incorporated into the harvested crops used in the production of goods or services. The blue water footprint is defined as the volume of surface and groundwater consumed during the production of a product. Meanwhile, grey water footprint refers to the volume of freshwater required to dilute pollutants so that the quality of the polluted water complies with ambient water quality standards, i.e. the Interim National Water Quality Standards for Malaysia (INWQS). Figure 1 illustrates the inputs and outputs of growing the selected crops. 


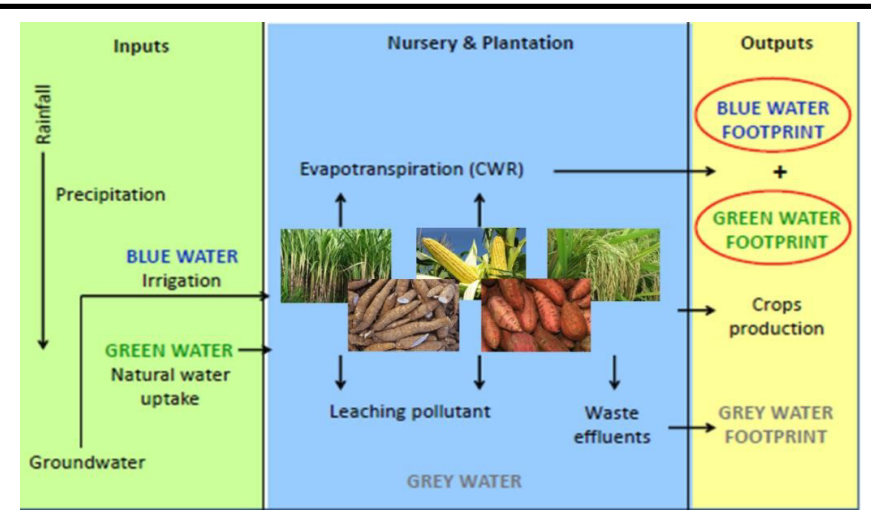

Figure 1: Framework of growing crops in water footprint approach

In agricultural context, the water footprint is a tool to quantify how much water has been consumed in growing a crop. The water footprint method of growing a crop is applicable to both annual and perennial crops [10]. The total water footprint of the crop cultivation process (WFcrop) was adapted from the general formula, as follows:

$$
\begin{gathered}
\text { WFcrop }=\text { WFcrop, } \text { green }+ \\
\text { WFcrop,blue } \\
\text { [m3/ton }]
\end{gathered}
$$

WFcrop $\square$ CWUYcrop,green $\square$ CWUcrop,blue $\square \square$ tonm3 //haha $\square \square \square$ $Y$

$$
\text { crop }
$$

The green water in the process of water footprint of crop (WFcrop,green, $\mathrm{m} 3 /$ ton) was calculated by dividing the green component in water use of crop with the crop yield ( $\mathrm{Y}$, ton/ha). The blue component (WFcrop,blue) was calculated in a similar way as the green water footprint and expressed in $\mathrm{m} 3 /$ ton.

\section{RESULTS AND DISCUSSION}

Figure 2(a-f) shows the result of total water footprint of 5 selected cash crops grown in 9 states in Peninsular Malaysia. The results indicate that per ton of crop produced, rice has the highest water requirement with 2317.24 $\mathrm{m} 3 /$ ton in off season and $2292.99 \mathrm{~m} 3 /$ ton for main season, followed by sugarcane (1457.34 m3/ton), maize (819.86 m3/ton), cassava (746.28 m3/ ton) and sweet potato (496.71 m3/ton), respectively. Off season refers to the rice grown in March-July, considered as dry months in Malaysia, while the main season refers to the rice grown in August to February, known as rainy or wet season [11].

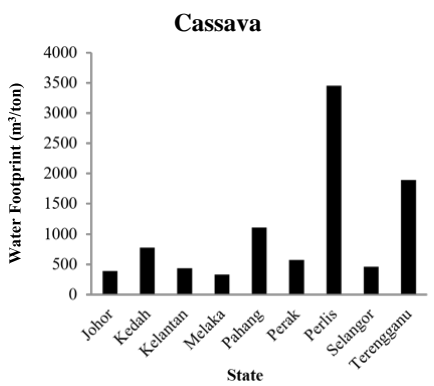

(a)

Rice Main Season

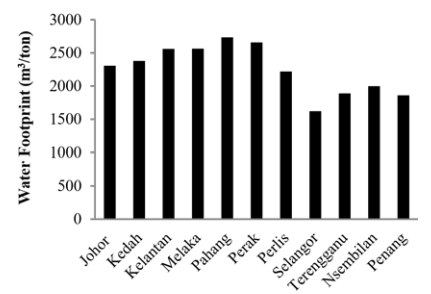

State (c)

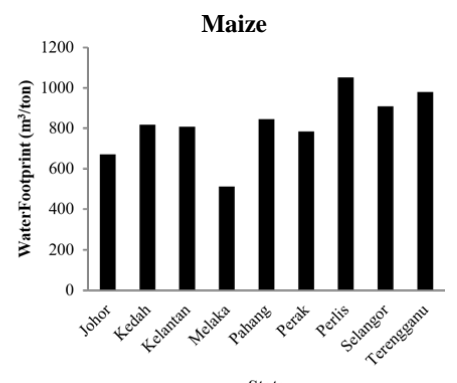

(b)

Rice Off Season

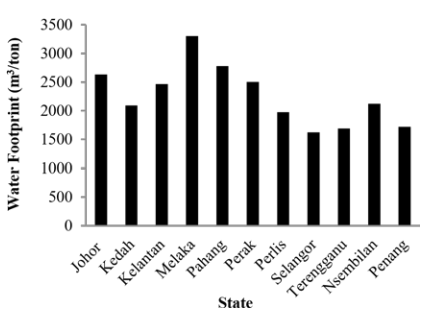

(d)

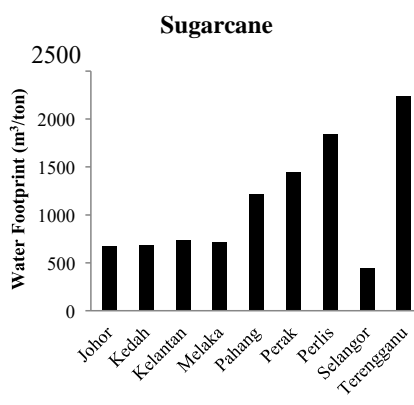

State

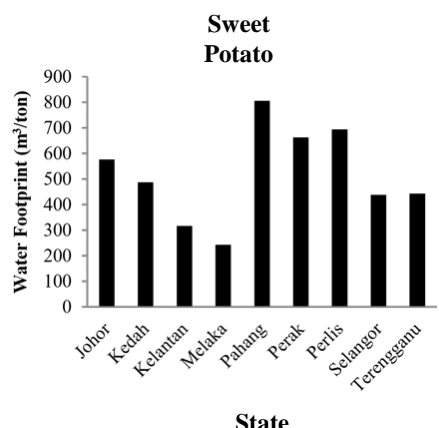

(f)
Figure 2: Total water footprint of selected cash crops in 9 states in Peninsular Malaysia. (a) cassava, (b) maize, (c) rice main season, (d) rice off season, (e) sugarcane and (f) sweet potato.

Meanwhile, Table 1 shows the comparison of blue and green water requirements of the five studied cash crops grown in Malaysia. It was found that rice cultivation in main season has the highest green water footprint (1536.60 m3/ton) compared to other selected cash crops cultivation in peninsular Malaysia, while sweet potato has the lowest green water footprint ( $409.52 \mathrm{~m} 3 / \mathrm{ton}$ ). The highest blue water footprint was recorded for rice in off season ( $949.31 \mathrm{~m} 3 /$ ton), whereas the lowest blue water footprint was estimated for cassava with $40.07 \mathrm{~m} 3 /$ ton.

Since rice is one of the most important crops in diet of Malaysian people, high production of rice was produced yearly in Malaysia [12]. In Thailand, rice has higher water requirement because of the paddy field cultivation is under flood condition. A research reported that rice is one of the largest water consumers in the world and requires large areas to irrigate the paddy field [13]. The country that consumed the largest volume of water for rice sector is India, followed by China, Indonesia, Bangladesh, Thailand, Myanmar, Vietnam and Philippines and Brazil [13]. However, the total water footprint of rice in Malaysia is lower compared to Thailand

\begin{tabular}{|c|c|c|c|c|}
\hline & (ton/ha) & Green & Blue & Total \\
\hline & \multicolumn{4}{|c|}{ Yield Water Footprint ( $\mathrm{m}^{3} /$ ton) Crops } \\
\hline Cassava & 15.57 & 706.21 & 40.07 & 746.28 \\
\hline Maize & 7.73 & 649.29 & 170.56 & 819.86 \\
\hline Rice Main Season & 4.06 & 1536.60 & 756.39 & 2292.99 \\
\hline Rice Off Season & 4.02 & 1367.93 & 949.31 & 2317.24 \\
\hline Sugarcane & 15.32 & 1226.19 & 231.14 & 1457.34 \\
\hline Sweet Potato & 20.45 & 409.52 & 87.19 & 496.71 \\
\hline
\end{tabular}
and Indonesia as shown in Table 2.

Table 1: The green, blue and total water footprint of selected cash crops in Malaysia.

The largest contribution to the total water footprint of each crop is the green component. For cassava, the green component contributes $95 \%$ to the total water footprint (blue and green water footprints), followed by sugarcane $(84 \%)$, sweet potato $(82 \%)$, maize $(79 \%)$ and paddy $(63 \%)$. This implies that most crops in Malaysia are mainly grown using rainwater. Malaysia received average rainfall of $2500 \mathrm{~mm}$ per year and this condition helps in growing crops in Malaysia. Blue water consumption, i.e. consumptive use of groundwater or surface water, generally has a larger effect on the environment than green water consumption [14]. Therefore, high dependent on surface water will contribute to water scarcity and some arid regions are highly vulnerable to water shortage induced by climate variability, such as prolonged drought event and deficiency of the rainfall rate.

Table 2 presents the previous studies on water footprint of some crops that were reported in other countries in Southeast Asia. In Thailand, the major rice consumed the largest water footprint compared to another crops cultivation [12]. A scientist also found that the water footprint of rice was also the highest as compared to maize and cassava [15]. The results from the previous studies were similar to the present study. The slight regional differences in water footprint of crops were caused by differences in climate and agricultural practices [15]. Hence, agricultural practices determine the yield, thus affecting the water footprint of product [15]. The variation in crop water requirements between countries also determined by the availability of modelling parameters, assumptions, limitations and input data needed for the assessment of water footprint of crops $[16,17,18]$. 
Table 2: Water footprint of crops reported in other countries of Southeast Asia

\begin{tabular}{|lcl|}
\hline Crops & $\begin{array}{r}\text { Water Footprint } \\
\left(\mathrm{m}^{3} / \text { ton }\right)\end{array}$ & Author \\
\hline Major rice & 2005 & $\begin{array}{l}\text { Shabbir et al. } \\
(2014)\end{array}$ \\
Maize & 982 & \\
Sugarcane & 399 & \\
Cassava & 160 & Bulsink et al. \\
Rice & 3473 & $(2010)$ \\
Maize & 2483 & \\
Cassava & 514 & \\
\hline
\end{tabular}

\section{CONCLUSION AND RECOMMENDATION}

Based on the study that has been carried out, the government needs to have an appropriate measurement to manage the sustainable use of water resource in order to avoid the issue of water scarcity due to the rising demand on the agricultural practices especially in the production of rice. A related agencies and departments involved in the agricultural industry need to further increase the efficiency of water consumption by revising the policy related in agriculture production that has been prepared for the farmers as a guideline in cultivating the crops. The productivity of agriculture can be improved by improving the agronomic management; in term of straw mulching, nutrient management and pest controls. In addition, by reducing the water use for land preparation through land levelling or reducing the period of land preparation can also help a wise water management in Malaysia.

In future, it is recommended that a comprehensive study needs to be conducted to assess the impacts of nutrient enrichment on freshwater resources by including grey water in the water footprint assessment. Since this study only included states in Peninsular Malaysia, other crops growing area in Sabah and Sarawak could be included as well in the future study. In future, LCA-based water footprint could be conducted to further assessing the impact of water consumption on areas of protection such as human health damage, ecosystem quality damage and natural resources depletion.

\section{ACKNOWLEDGEMENT}

Marlia Mohd Hanafiah was financed by research grants: FRGS/2/2013/ STWN01/UKM/03/1 and TD2014-012.

\section{REFERENCES}

[1] United Nations Development Programme (UNDP). 2006. Beyond scarcity: Power, poverty and the global water crisis. Human Development Report 2006. United Nations Development Programme. New York, USA.

[2] Lloyd's $360^{\circ}$ Risk Insight. 2010. Global Water Scarcity: risks and challenges for business. London, Lloyd's.

[3] World Water Assessment Programme (WWAP). 2012. The United Nations World Water Development Report 4: Managing Water under Uncertainty and Risk. Paris, UNESCO.

[4] Zaim, F., Bahaman, A. S. and Haslinda, A. 2013. Paddy Industry and Paddy Farmers Well-being: A Success Recipe for Agriculture Industry in
Malaysia. Asian Social Science, 9, 177-181.

[5] Abdul Samad, M. N. S., Hanafiah, M.M., Abdul Hasan, M. J., Mohd Ghazali, N. F., and Harun S. N. 2017. Ratio of Water Withdrawal to Availability in Kelantan Watersheds, Malaysia. Journal of Clean Water, Air \& Soil (J Clean WAS), 1(1), 40-44.

[6] Hoekstra, A. Y., and Hung, P. Q. 2002. Virtual water trade: A quantification of virtual water flows between nations in relation to international crop trade. Value of Water. Research Report Series No. 11 (UNESCO-IHE): the Netherlands.

[7] Babel, M. S., Shrestha, B., and Perret, S. 2010. Hydrological impact of biofuel production: A case study of the Khlong Phlo Watershed in Thailand," Agricultural Water Management, 101, 8-26.

[8] Hoekstra, A.Y. 2003. Virtual Water Trade: Proceedings of the International Expert Meeting on Virtual Water Trade; Value of Water Research Report Series No. 12; The United Nations Educational, Scientific and Cultural Organization-International Institute for Hydraulic and Environmental Engineering (UNESCO-IHE): Delft, the Netherlands.

[9] Chapagain, A. K., and Hoekstra, A. Y. 2004. Water footprints of nations. Value of Water Research Report Series Vol. 16. Delft, The Netherlands.UNESCO-IHE.

[10] Hoekstra, A.Y. 2011. The global dimension of water governance: Why the river basin approach is no longer sufficient and why cooperative action at global level is needed. Water, 3(1), 21-46.

[11] Kemubu Agricultural Development Authority (KADA). 2017. Paddy Planting Schedule. Retrieved from http://www.kada.gov.my/en/web/ guest/jadual-tanaman-padi.

[12] Gheewala, S. H., Silalertruksa, T., Nilsalab, P., Mungkung, R., Perret, S. R., and Chaiyawannakarn, N. 2014. Water Footprint and Impact of Water Consumption for Food, Feed, Fuel Crops Production in Thailand. Water, 6, 1698-1718.

[13] Chapagain, A. K. and Hoekstra, A. Y. 2011. The blue, green and grey water footprint of rice from both a production and consumption perspective. Ecological Economics, 70, 749-758.

[14] Falkenmark, M., and Rockstr"om, J. 2004. Balancing water for humans and nature: The new approach in ecohydrology. London, UK: Earthscan.

[15] Bulsink, F., Hoekstra, A. Y. and Booij, M. J. 2010. The water footprint of Indonesian provinces related to the consumption of crop products. Hydrology and Earth System Sciences, 6 (4), 5115-5137.

[16] Aminordin, M. M., and Hanafiah, M. M. 2014. Water Footprint Assessment of Oil Palm in Malaysia: A Preliminary Study. AIP Conference Proceedings, 1614, 803-807.

[17] Mohd Ghazali, N. F., and Hanafiah, M. M. 2016. Malaysian water footprint accounts: Blue and green water footprint of rice cultivation and the impact of water consumption in Malaysia. AIP Conference Proceedings, $1784,060025$.

[18] FAO. 2000. Climate change, water and food security. FAO Water Reports 36. Rome, Italy. 